\title{
HUBUNGAN ANTARA REGULASI DIRI DENGAN PROKRASTINASI AKADEMIK PADA MAHASISWA KORPS SUKARELA PALANG MERAH INDONESIA (KSR PMI) DI UNIVERSITAS NEGERI PADANG
}

\author{
Lidia Nisva , Ria Okfrima \\ Universitas Putra Indonesia "YPTK" Padang \\ Email penulis: lidianisva02@gmail.com / riaokfrima@upiyptk.ac.id
}

\begin{abstract}
This research was carried out to PMI KSR students in Padang State. This study aims to see whether there is a relationship between Self Regulation and Academic Procrastination at Students of the Voluntary Corps of the Indonesian Red Cross (KSR PMI) at Padang State University. The population in this study was the 2014 PMI KSR students who were still active in the organization. The research subjects used Purposif sampling technique. Sampling technique with certain considerations. Measuring instrument used is the self-regulation skla researchers collated based on the theory proposed in 2014 and Procrastination Purnawasari the researchers collated based on the theory proposed by Gufron 2010. Data analysis methods were used to test the hypothesis in this research is by using correlation product moment(person)which shows that $\mathrm{r}=-0,378$ with a value of $\mathrm{p}=0.016$, meaning that there is a significant relationship between the relationship between self-regulation and the 2014 KSR PMI student procrastination at Padang State University. Means the research hypothesis is accepted. The effective contribution of the self-regulation variable with the 2014 PMR KSR student academic procrastination in Padang is $14 \%$.
\end{abstract}

Keywords: Self Regulation, Academic Procrastination,Students (PMR KSR)

\begin{abstract}
ABSTRAK
Penelitian ini dilakukan kepada mahasiswa KSR PMI di Negeri Padang. Penelitian ini bertujuan untuk melihat apakah terdapat Hubungan antara Regulasi Diri Dengan Prokrastinasi Akademik Pada Mahasiswa Korps Sukarela Palang Merah Ind onesia(KSR PMI ) di Universitas Negeri Padang. Populasi dalam Penelitian ini adalah mahasiswa KSR PMI angkatan 2014 yang masih aktif dalam organisasi. Adapun subjek penelitian menggunakan teknik Purposif sampling. Teknik penentuan sampel dengan pertimbangan tertentu. Alat ukur yang digunakan adalah skla regulasi diri yang peneliti susun berdasarkan teori yang dikemukakan Purnawasari 2014 dan Prokrastinasi yang peneliti susun berdasarkan teori yang dikemukakan oleh Gufron 2010. Metode analisis data yang digunakan untuk pengujian hipotesis dalam penelitian ini adalah dengan menggunakan korelasi Product momen (person) yang menunjukkan bahwa $r=-0,378$ dengan nilai $\mathrm{p}=0,016$, artinya terdapat hubungan signifikan antara hubungan antara regulasi diri dengan prokrastinasi akademik mahasiswa KSR PMI angkatan 2014 di Universitas Negeri Padang. Berarti hipotesis penelitian diterima. Adapun sumbangan efektif dari variabel regulasi diri dengan prokrastinasi akademik mahasiswa KSR PMI angkatan 2014 di Negeri Padang sebesar $14 \%$.
\end{abstract}

Kata Kunci : Regulasi Diri, Prokrastinasi Akademik,Mahasiswa (KSR PMI) 


\section{PENDAHULUAN}

Mahasiswa sebagai elemen masyarakat yang mempunyai kekuatan untuk memperbaiki dan memperbarui kondisi masyarakat, bangsa dan negara, haruslah mempunyi kapasitas diatas rata-rata mayoritas masyarakat kita. Mahasiswa diharapkan memiliki pengetahuan yang luas dan mempunyai kemampuan (skill), visi dan karakter yang lebih maju dibandingkan masyarakat pada umumnya. Mahasiswa mampu mengembangkan kemampuan dan keterampilan bukan hanya dari aktivitas perkuliahan akan tetapi dari berbagai jenis kegiatan di dalam kampus, salah satunya menjadi anggota sebuah organisasi. Organisasi diminati oleh mahasiswa untuk menyalurkan bakat, minat, dan kemampuan mereka (Widayanto, 2011). ${ }^{[18]}$.

Salah satu organisasi kemahasiswaan yang ada di kampus yaitu organisasi KSR PMI yaitu oganisasi kemahasiswa yang mengikuti kegiatan dan terdaftar sebagai anggota dari KSR PMI disebut juga dengan mahasiswa aktivis. Terdapat dua beban tugasyang dimiliki oleh Mahasiswa aktivis didalam melakukan aktifitasnya, yaitu yang pertama sebagai mahasiswa yang mana memiliki kewajiban akademik dengan segala tugas dan permasalahannya. Di sisi yang lain sebagai aktivis yang mana mereka memiliki kewajiban dan dituntut untuk aktif didalam segala kegiatan yang dirancangkan oleh KSR PMI. Dua peran dengan tugasnya masing-masing dan terkadang harus diselesaikan dalam waktu yang bersaman menjadikan mahasiswa tersebut melakukan prokrastinasi (menunda-nunda pekerjaan) seperti halnya yang diungkapkan oleh Burka \& Yuen (dalam Wibowo, 2013:) bahwa prokrastinasi yang dilakukan oleh orang dewasa pada umumnya disebabkan oleh banyaknya kegiatan yang dilakukan. Berbagai kegiatan aktivitas dalam menjalankan tugas dan tanggung jawab di organisasi mempunyai dampak positif maupun negatif. Adapun dampak positif dari keaktivan dalam organisasi berdasarkan hasil penelitian Setyono (2013) ${ }^{[21]}$ antara lain: a. Mudah bergaul dan mendapat banyak relasi. b. Memilki pengalaman yang lebih dari pada mahasiswa yang tidak aktif dalam berorganisasi. c. Memiliki sifat mandiri tidak tergantuk dengan orang lain. d. Berpikiran luas dan rasional. e. Rasa solidaritas yang tinggi terhadap sesame mahasiswa terutama anggota yang ada di dalam organisasi yang diikuti . Selain itu dampak negatif dari keaktifan dalam organisasi berdasarkan hasil penelitian Setyono (2013) ${ }^{[2])}$ antara lain: a. Mengikuti perkuliahan sering terlambat dan bahkan sering membolos demi mengikuti kegiatan organisasi yang diikuti. b. Prestasi akademik kurang baik bahkan cenderung menurun.c. Seringkali tidak tepat waktu dalam menyelesaikan perkuliahan. Sering tidak tepat waktu dalam menyelesaikan perkuliahan ini disebut jugan dengan prokrastinasi akademik

Solomon dan Rothblum (dalam Fitriya \& Lukmawati, 2016), ${ }^{[8]}$ menuturkan terdapat tiga faktor yang mempengaruhi prokrastinasi akademik yaitu : pertama, takut akan kegagalan adalah munculnya kecemasan dan rasa bersalah apabila tidak dapat menggapai tujuan yang ingin digapai. Kedua, adanya rasa tidak suka pada tugas. Hal ini bersangkutan dengan perasaan buruk terhadap tugas atau pekerjaan yang dihadapi. Perasaan dimana seseorang merasa terlalu dibebani oleh tugas yang amat berlebihan, rasa tidak puas, serta tidak adanya perasaan suka ketika melaksanakan tugas yang diberikan. Ketiga, sifat yang bergantung secara berlebihan pada orang lain dan banyak memerlukan bantuan dari orang lain, sikap yang kurang tegas, sikap yang suka melawan dan memiliki kesulitan untuk mengambil sebuah keputusan (Fitriya \& Lukmawati, 2016). ${ }^{[8]}$ Muhid (dalam Hendrianur, 2015).$^{[10]}$ mengatakan bahwa terdapat aspekaspek pada seseorang yang mempengaruhinya untuk melakukan perilaku prokrastinasi, salah satunya adalah karena rendahnya regulasi diri. Regulasi diri menunjuk pada pola pikir, perilaku dan perasaan yang mengarah pada perolehan tujuan yang dimiliki tiap-tiap individu (Park \& Sperling, 2012) ${ }^{[22] .}$ Ketika tujuan tersebut berkaitan dengan pembelajaran, maka regulasi diri yang dimaksud adalah self-regulated learning (Kusaeri \& Mulhamah, 2016). ${ }^{[15]}$ Regulasi diri yang berkaitan dengan pembelajaran biasa dipakai pelajar ataupun mahasiswa untuk mengelola kognisinya (dengan penggunaan strategi-strategi kognitif dan metakognitif) dan juga strategi mengepengetahuan (Pintrich dalam Kusaeri \& Mulhamah, 2016). ${ }^{[15]}$ Maka dari itu, regulasi diri yang berhubungan dengan proses pembelajaran seharusnya memadukan banyak hal tentang belajar efektif (Kusaeri \& Mulhamah, 2016). ${ }^{[15]}$. 
Perilaku regulasi diri memiliki 7 tahapan, yaitu: (1) Tahapan menerima informasi yang relevan adalah ketika individu menangkap suatu informasi awal yang penting. Informasi yang diperoleh dapat dihubungkan dengan informasi-informasi yang sebelumnya diperoleh oleh individu tersebut (Manab, 2016). ${ }^{[14]}$ (2) Tahapan mengevaluasi informasi adalah ketika seseorang melakukan evaluasi pada informasi yang ia terima, kemudian membandingkan informasi tersebut dengan norma-norma yang berlaku. Tahapan evaluasi ini merupakan tahapan dimana seseorang memberikan perbandingan antara pendapat individu tersebut yang ia terima sebelumnya dengan permasalahan yang ada di lingkungan luar (Manab, 2016). ${ }^{[14]}$ (3) Tahapan memicu perubahan adalah tahap setelah seseorang melakukan evaluasi pada informasi yang ia terima, yaitu individu tersebut melakukan perubahan. (4) Tahapan mencari pilihan adalah memikirkan pilihan-pilihan kemudian menetapkan pilihan-pilihan yang ada tersebut. Dapat dikatakan juga bahwa tahapan ini merupakan tahapan dimana seseorang mencari solusi untuk perbedaan masalah yang didapat dari tahapan sebelumnya, yaitu tahapan evaluasi (Manab, 2016). [14] (5) Tahapan merumuskan sebuah renana adalah ketika seseorang melakukan pendeskripsian serta menyusun sebuah rencana. Tahapan ini dapat dikatakan juga sebagai sebuah tahap dimana seseorang menetapkan perencanaan serta melakukan perhitungan dalam hal-hal seperti waktu, lokasi, dan sebagainya (Manab, 2016). [14] (6) Tahapan mengimplementasikan rencana adalah ketika individu menerapkan dan melaksanakan rencana yang telah ia buat. (7) Tahapan menilai keefektifan rencana adalah melihat dan menelusuri apakah sebuah rencana dapat berjalan efektif apa tidak dan seberapa maksimal rencana tersebut dapat dilakukan untuk mencapai tujuan yang diinginkan.

Berdasarkan hasil wawancara yang dilakukan di Universitas Negeri Padang (UNP) pada Kamis tanggal 12 Oktober 2018, ada 5 orang mahasiswa terdaftar sebagai anggkota KSR PMI Mahasiswa anggkatan 2014 yang mengikuti organisasi KSR PMI terdapat mahasiswa yang aktif dalam kegiatan organisasi mempunyai masalah dalam membagi waktu antara jadwal kuliah yang padat dan kegiatan berorganisasi. Mahasiswa lebih memilih tidak hadir dalam proses PBM di kelas, karena mereka sering terlambat datang ke kampus disebabkan mereka kurang tidur. Mahasiswa yang aktif di organisasi KSR PMI sering menunda-nunda dalam mengerjakan tugas. Karena mereka merasa banyak kesibukan dalam berorganisasi KSR PMI dan mereka menunda tugas yang telah diberikan dosen kepada mereka sebelum deadline. Ketika proses pembelajaran dikelas mahasiswa sibuk maminkan handphone. Sehingga ketika dosen memberikan tugas individu maupun kelompok mereka tidak mengerjakannya yang telah diberikan dosen kepada mereka. Ada juga beberapa mahasiswa yang mengatakan kurang memiliki motivasi dari diri sendiri, sehingga lebih memilih untuk mengerjakan tugas secara berkelompok bersama teman-teman yang lain. Mahasiswa yang ikut dalam organisasi mengatakan nilai akademik mereka menurun mereka juga mengatakan bahwa mereka kurang memiliki motivasi untuk mengerjakan tugas kemudian mereka mengatakan bahwa nilai IPK mereka mengalami penurunan dari semester sebelumnya adapun penurunan IPK mereka adalah sebagai berikut, dari 3,40 menjadi 2,98, 3,60 menjadi 3,00,2,80 menjadi 2,60, 2,75, menjadi 2,50 dan 2,90, menjadi 2,75.

Penelitian mengenai prokrastinasi sudah pernah dilakukan oleh Srantih, (2016) dengan judul Pengaruh Perfeksionisme Terhadap Prokrastinasi Akademik Pada Mahasiswa yang Sedang Mengerjakan Skripsi. Penelitian ini juga dilakukan oleh Siti Solihah (2015) dengan judul Hubungan Perfeksionisme Dan Regulasi Diri Dengan Prokrastinasi Akademik. Berikutnya penelitian oleh Akhmad Faisal Hidayat (2013) dengan judul Hubungan Regulasi Diri dengan Prestasi Belajar Kalkulus II Ditinjau dari aspek Metakognisi, Motovasi dan Perilaku. perbedaan peneliti yang akan peneliti lakukan dengan peneliti sebelumnya adalah waktu penelitian, subjek penelitian, jumlah sampel penelitian dan lokasi penelitian.

Berdasarkan fenomena yang telah dikemukakan di atas maka peneliti tertarik untuk melakukan penelitian dengan judul "Hubungan Antara Regulasi Diri Dengan Prokrasrinasi Pada Mahasiswa Korps Sukarela Palang Merah Indonesia (KSR PMI) di Universitas Negeri Padang 


\section{TINJAUAN LITERATUR Prokrastinasi Akademik}

Menurut Ferrari dkk (dalam Ghufron \& Risnawita, 2010). ${ }^{[9]}$ prokrastinasi akademik adalah jenis penundaan yang dilakukan pada jenis tugas formal yang berhubungan dengan tugas akademik, misalnya tugas sekolah atau tugas kursus. Solomon dan rothblum (dalam Zakiyah dkk, 2010).$^{[28]}$ mengungkapkan bahwa prokrastinasi akademik mengacu pada kecenderungan untuk menangguhkan atau menunda mengerjakan tugas yang berhubungan dengan studi seseorang, sehingga tidak dapat menyelesaikan tugas pada waktunya.

\section{Aspek-aspek Prokrastinasi Akademik}

Ferrari dkk dan shell (dalam Maharani, 2016).$^{[13]}$ mengatakan bahwa sebagai suatu perilaku penundaan, prokrastinasi akademik dapat termanifestasikan dalam indikator tertentu yang dapat diukur dan diamati, aspek-aspek tersebut berupa:

a. Perceived time,

Seseorang yang cenderung prokrastinasi adalah orang yang gagal menepati deadline. Mereka berorientasi pada masa sekarang dan tidak mempertimbangkan masa mendatang, prokrastinator tahu bahwa tugas yang dihadapinya harus segera diselesaikan, tetapi ia menunda-nunda untuk mengerjakannya atau menunda menyelesaikannya jika ia sudah memulai pekerjaannya tersebut.

b. Intention-action

Celah antara keinginan dan tindakan, perbedaan antara keinginan dengan tindakan senyatanya itu terwujud pada kegagalan siswa dalam mengerjakan tugas akademik walaupun siswa tersebut punya keinginan untuk mengerjakannya. Hal ini terkait pula dengan kesenjangan waktu antara rencana dan kinerja aktual. Prokrastinator mempunyai kesulitan untuk melakukan sesuatu sesuai dengan batas waktu.

\section{c. Emotional distress}

Adanya perasaan cemas saat melakukan prokrastinasi. Prilaku menunda-nunda akan membawa perasaan tidak nyaman pada pelakunya, konsekuensi negatif yang ditimbulkan memicu kecemasan dalam diri pelaku prokrastinasi. Pada mulanya siswa tenang karena merasa waktu yang tersedia masih banyak. Tanpa terasa waktu sudah habis, ini menjadikan meraka cemas karena belum menyelesaikan tugas.

d. Perceived ability

Keyakinan terhadap kemampuan diri, walaupun prokrastinasi tidak berhunbungan dengan kemampuan kognitif seseorang, namun keragu-raguan terhadap kemampuan dirinya dapat menyebabkan seseorang melakukan prokrastinasi. Hal ini ditambah dengan rasa takut akan gagal menyebabkan seseorang menyalahkan dirinya sebagai yang tidak mampu, untuk menghindari munculnya dua perasaan tersebut maka seseorang dapat menghindari tugas-tugas sekolah karena takut akan pengalaman kegagalan.

\section{Regulasi Diri}

Brown (dalam Purnamasari, 2014). ${ }^{[18]}$ self regulation atau regulasi diri adalah kemampuan individu untuk merencanakan, mengarahkan, dan memonitor perilaku untuk mencapai suatu tujuan tertentu dengan melibatkan unsur fisik, kognitif, emosional, dan social. Bandura (dalam Istriyanti dan Simarmata, 2014) menyatakan regulasi diri merupakan kemampuan untuk mengontrol perilaku sendiri dan salah satu dari sekian penggerak utama kepribadiaan manusia yang terdiri dari pengamatan, penilaian dan respon diri.

\section{Aspek-aspek Regulasi Diri}

Menurut Schunk \& Zimmerman (dalam Ghufron dan Risnawati, 2011). ${ }^{[9]}$ terdapat tiga aspek dari belajar berdasarkan regulasi diri yaitu :

a. Metakognisi 
Metakognisi merupakan kemampuan individu dalam merencanakan, mengorganisasi atau mengatur, mengintruksi diri, memonitor dan melakukan evaluasi dalam aktivitas belajar.

b. Motivasi

Motivasi intrinsik ini muncul dari dalam diri individu sendiri tanpa ada paksaan atau dorongan dari orang lain, tetapi atas dasar kemauan sendiri.

c. Perilaku

Perilaku aktif dalam regulasi diri merupakan upaya individu untuk mengatur dirinya, menyeleksi dan memanfaatkan lingkungan yang mendukung aktivitas belajar.

\section{HIPOTESIS}

Berdasarkan keterangan yang telah dijelaskan di atas maka dapat diajukan hipotesis dalam penelitian ini adalah terdapat hubungan antara regulasi diri dengan prokrastinasi akademik pada mahasisa KSR PMI di Universitas Negeri Padang". Artinya semakin tinggi regulasi diri mahasiswa, maka semakin rendah prokrastinasi akademik mahasiswa. Sebaliknya, semakin rendah regulasi diri mahasiswa, maka semakin tinggi prokrastinasi akademik mahasiswa.

\section{METODE PENELITIAN}

Penelitian kuantitatif adalah penelitian ilmiah yang sistematis terhadap bagian-bagian dan fenomena serta hubungan-hubungannya. Tujuan penelitian kuantitatif adalah mengembangkan dan menggunakan model-model matematis, teori-teori dan/atau hipotesis yang berkaitan dengan fenomena alam. Proses pengukuran adalah bagian yang sentral dalam penelitian kuantitatif karena hal ini memberikan hubungan yang fundamental antara pengamatan empiris dan ekspresi matematis dari hubungan-hubungan kuantitatif.

\section{Identifikasi Variabel Penelitian}

Menurut Sugiyono (2014) ${ }^{[23]}$ variabel penelitian adalah suatu atribut atau sifat atau nilai dari orang, obyek atau kegiatan yang mempunyai variasi tertentu yang ditetapkan oleh peneliti untuk dipelajari dan kemudian ditarik kesimpulannya.

1. Adapun variabel independen dalam penelitian ini adalah Regulasi Diri (X)

2. Adapun variabel dependen dalam penelitian ini adalah Prokrastinasi Akademik (Y)

\section{Definisi Operasional Variabel Penelitian}

Definisi operasional adalah suatu definisi mengenai variabel yang dirumuskan berdasarkan karakteristik-karakteristik tersebut yang dapat diamati (Azwar, 2014). ${ }^{[5]}$

\section{Regulasi Diri}

Adapun definisi operasional variabel dalam penelitian ini yaitu:

Regulasi diri adalah kemampuan untuk mengontrol perilaku sendiri dan salah satu dari sekian penggerak utama kepribadiaan manusia sehingga dapat digunakan sebagai alat adaptasi terhadap perubahan yang ada di sekelilingnya. Dalam penelitian ini regulasi diri dapat diukur dengan menggunakan skala yang disusun berdasarkan aspek-aspek regulasi diri diukur dengan menggunakan skala yang disusun berdasarkan aspek-aspek regulasi diri yaitu metakognitif, motivasi, dan perilaku.

\section{Prokrastinasi Akademik}

Prokrastinasi akademik adalah perilaku menunda-nunda untuk memulai atau menyelesaikan tugas-tugas akademik yang dilakukan secara sengaja dan dilakukan berulangulang tanpa memandang alasan apapun sehingga mengakibatkan dampak negatif kepada pelaku seperti mengatakan memperoleh IPK akademik rendah dan rata-rata kondisi kesehatan yang kurang baik. Dalam penelitian ini prokrastinasi diukur dengan menggunakan skala yang disusun berdasarkan aspek-aspek prokrastinasi yaitu perceived time, intention-action, emotional distress, perceived ability. 


\section{Populasi dan Sampel}

\section{Populasi}

Populasi adalah wilayah generalisasi yang terdiri atas objek atau subjek yang mempunyai kualitas dan karakteristik tertentu yang ditetapkan peneliti untuk dipelajari dan kemudian ditarik kesimpulannya (Sugiyono, 2011). ${ }^{[23]}$ Populasi pada penelitian ini Mahasiswa KSR PMI di Universitas Negeri Padang, yang berjumlah 300 mahasiswa.

\section{Sampel}

Teknik pengambilan sampel pada penelitian ini adalah non probability sampling. Non probability sampling adalah teknik pengambilan sampel yang tidak memberi peluang atau kesempatan sama bagi setiap unusur atau anggota populasi untuk dipilih menjadi sampel (Sugiyono, 2012). ${ }^{[23]}$ Adapun yang menjadi sampel dalam penelitian ini adalah dengan kriteria Mahasiswa angkatan 2014 yang masih aktif dalam kegiatan organisasi KSR PMI di Universitas Negeri Padang. Berdasarkan uraian di atas, maka jumlah sampel yang nantinya akan menjadi subjek dalam penelitian ini adalah Mahasiswa KSR PMI di Universitas Negeri Padang berjumlah

40 orang.

\section{Metode dan Alat Pengumpulan Data Alat ukur penelitian}

Skala ini terdiri dari pertanyaan yang bersifat favourabel dan unfavourabel yang masing-masing terdiri dari empat alternatif jawaban (Azwar, 2012). ${ }^{[23]}$ Subjek diminta untuk memberikan penilaian sampai seberapa jauh kesesuaian tiap aitem dengan keadaan subjek sendiri dengan menulis salah satu dari 4 alternatif jawaban yang disediakan. Adapun alternatif jawaban ini adalah Sangat Sesuai (SS), Sesuai (S), Tidak Sesuai (TS) dan Sangat Tidak Sesuai (STS).

\section{Skala Regulasi Diri}

Skala yang digunakan untuk mengukur regulasi diri dalam penelitian ini adalah skala yang disusun berdasarkan aspek-aspek regulasi diri yaitu metakognitif, motivasi, dan perilaku. Regulasi diri dari tiga aspek yaitu metakognisi, motivasi, dan perilaku.

\section{Skala Prokrastinasi Akademik}

Skala yang digunakan untuk mengukur prokrastinasi dalam penelitian ini adalah skala yang disusun berdasarkan aspek-aspek prokrastinasi yaitu perceived time, intention-action, emotional distress, perceived ability.

\section{Uji coba alat ukur Uji Validitas}

Validitas berasal dari kata validity yang mempunyai arti sejauh mana ketepatan dan kecermatan suatu alat ukur dalam melakukan fungsi ukurnya. Penentuan item valid atau tidaknya menggunakan kriteria $r_{x y} \geq 0,3$ (Sugiyono, 2014). ${ }^{[23]}$ Suatu data skala dikatakan valid jika koefisien korelasi lebih besar atau sama dengan $0,3\left(\mathrm{r}_{\mathrm{xy}} \geq 0,30\right)$ dan sebaliknya data skala dikatakan gugur jika koefisien korelasi lebih kecil dari $0,3\left(\mathrm{r}_{\mathrm{xy}}<0,30\right)$.

\section{Uji Reliabilitas}

Reliabilitas yaitu konsistensi atau ketepercayaan hasil ukur yang mengandung makna kecermatan pengukuran (Azwar, 2012). ${ }^{[6]}$ Koefisien reliabilitas berada dalam rentang angka 0 sampai 1,00. Semakin tinggi koefisien reliabilitas maka semakin tinggi reliabilitas hasil pengukuran sebaliknya jika koefisien reliabilitas semakin rendah dengan mendekati angka 0 maka akan semakin rendah pula reliabilitas hasil pengukuran (Azwar, 2012). ${ }^{66}$ Ataupun perhitungan reliabilitas alat ukur pada penelitian ini menggunakan pengujian koefisien reliabilitas Alpha cronbach dengan menggunakan bantuan program IBM SPSS 21.0. 


\section{HASIL DAN PEMBAHASAN}

\section{Validitas Skala Regulasi Diri}

Koefisien validitas ditetapkan sebesar $\geq 0$, 30, sehingga diperoleh hasil dari jumlah aitem awal 42 pernyataan, gugur 15 aitem sehingga jumlah aitem yang digunakan adalah 27 aitem, dengan nilai corrected item-total correlation berkisar antara 0,373 sampai dengan 0,762 sedangkan koefisien reliabilitasnya sebesar 0,920 .

\section{Validitas Skala Prokrastinasi Akademik}

Koefisien validitas ditetapkan sebesar $\geq 0$, 30 sehingga diperoleh hasil dari jumlah aitem awal 40 pernyataan, gugur 10 aitem sehingga jumlah aitem yang digunakan adalah 30 pernyataan, dengan nilai corrected item-total correlation berkisar antara 0,403 sampai dengan 0,760 sedangkan koefisien reliabilitasnya sebesar 0,932 .

\section{Reliabilitas Skala Regulasi Diri Dengan ProkrastinasiAkademik}

Reliabilitas pada skala regulasi diri melalui teknik analisis Alpha Cronbach. Setelah melalui proses penghitungan hasil try out, maka diperoleh nilai koefisien reliabilitas sebesar 0,920. Hal ini menunjukkan bahwa alat ukur skala regulasi diri memiliki reliabilitas yang tinggi.

Hasil uji reliabilitas pada skala prokrastinasi akademik melalui teknik analisis Alpha Cronbach diperoleh koefisien sebesar 0,932. Hal ini menunjukkan bahwa alat ukur skala prokrastinasi akademik memiliki reliabilitas yang sangat tinggi, sehingga reliabel untuk digunakan dalam penelitian.

\section{Hasil Penelitian}

Penelitian dilakukan dengan menyebarkan skala Regulasi Diri dan Prokrastinasi Akademik pada Mahasiswa KSR PMI di Universitas Negeri Padang. Pengambilan data dilakukan pada hari Sabtu tanggal 12 Januari 2019. Skala yang telah diisi oleh Organisasi KSR PMI Universitas Negeri Padang mahasiswa langsung dikembalikan kepada peneliti. Sebelum melakukan uji hipotesis terlebih dahulu peneliti melakukan uji asumsi terhadap data hasil penelitian yang meliputi uji normalitas sebaran dan uji linieritas hubungan antar variabel penelitian.

\section{Uji Normalitas}

Uji normalitas digunakan untuk mengetahui apakah populasi data berdistribusi normal atau tidak. Uji normalitas dalam penelitian ini menggunakan uji analisis One Sample kolmogorov smirnov dengan menggunakan taraf signifikansi 0,05 (Priyantno, 2008). ${ }^{[17]}$ Berdasarkan hasil pengolahan data dengan menggunakan program IBM SPSS 21.0. Berdasarkan tabel 1 di atas, maka diperoleh nilai signifikansi pada skala regulasi diri diperoleh nilai signifikansi sebesar $\mathrm{p}=0,820$ dengan $\mathrm{KSZ}=0,631$ hasil tersebut menunjukan bahwa nilai $\mathrm{p}>0,05$, artinya sebaran terdistribusi secara normal, sedangkan untuk skala prokrastinasi akademik sebesar $\mathrm{p}=0,149$ dengan $\mathrm{KSZ}=1,139$ hasil tersebut menunjukan bahwa nilai $\mathrm{p}>0,05$, artinya sebaran skala prokrastinasi akademik terdistribusi secara normal.

\section{Uji Linieritas}

Uji linieritas bertujuan untuk mengetahui apakah dua variabel mempunyai hubungan yang linier atau tidak signifikan dengan menggunakan test for linearity pada taraf signifikansi 0,05 . Dua variabel dikatakan mempunyai hubungan yang linier bila signifikansi (linearity) kurang dari 0,05 (Priyatno, 2008). ${ }^{[17]}$ Berdasarkan hasil pengolahan data dengan menggunakan program IBM SPSS 21.0. Berdasarkan tabel 2 di atas, diperoleh nilai $\mathrm{F}=$ 6,362 dengan signifikansi sebesar $\mathrm{p}=0,022(\mathrm{p}<0,05)$, artinya varians pada skala regulasi diri dan prokrastinasi akademik tergolong linier. 


\section{Uji Hipotesis}

Pengolahan data penelitian tentang hubungan antara regelasi diri dan prokrastinasi akademik pada 40 orang Mahasiswa Organisasi KSR PMI Universitas Negeri Padang menggunakan uji statistik pearson product moment dengan bantuan IBM SPSS 21,0. Hasil perhitungan uji korelasi product moment pearson dengan bantuan IBM SPSS 21.0, maka diperoleh hasil sebagai berikut:

Tabel 1: Hasil Uji Korelasi Antara Skala Regulasi Diri dan Prokrastinasi Akademik

\begin{tabular}{|c|c|c|c|l|}
\hline $\mathrm{P}$ & $(\alpha)$ & Nilai Korelasi $(\mathrm{r})$ & $\mathrm{R}$ square & \multicolumn{1}{c|}{ Kesimpulan } \\
\hline 0,016 & 0.05 & $-0,378$ & 0,143 & $\begin{array}{l}\text { sig (2-tailed) } 0,016<0,05 \text { level of } \\
\text { significant }(\alpha), \text { berarti hipotesis } \\
\text { diterima. }\end{array}$ \\
\hline
\end{tabular}

Berdasarkan hasil uji korelasi di atas, terlihat korelasi yang signifikan antara skala regelasi diri dan prokrastinasi akademik, yaitu sebesar $r=-0,378$ dengan taraf signifikansi $p$ $=0,016$. Hal ini menunjukkan korelasi yang negatif, berarti jika regulasi diri tinggi, maka prokrastinasi akademik Mahasiswa organisasi KSR PMI Universitas Negeri Padang akan rendah dan sebaliknya jika regulasi diri rendah, maka prokrastinasi akademik Mahasiswa organisasi KSR PMI Universitas Negeri Padang tersebut akan tinggi. Hal ini diperkuat dengan hasil uji signifikansi dengan bantuan IBM SPSS Statistic versi 21.0, didapatkan $\mathrm{p}=$ $0,016<0,05$ level of significant $(\alpha)$, yang berarti terdapat hubungan yang signifikan antara regulasi diri dengan prokrastinasi akademik Mahasiswa Organisasi KSR PMI Universitas Negeri Padang.

Tabel 2: Norma Kategorisasi

\begin{tabular}{|c|c|}
\hline Norma & Kategorisasi \\
\hline$X<(\mu-1,0 \sigma)$ & Rendah \\
\hline$(\mu-1,0 \sigma) \leq X<(\mu+1,0 \sigma)$ & Sedang \\
\hline$(\mu+1,0 \sigma) \leq X$ & Tinggi \\
\hline
\end{tabular}

Keterangan :

$\mathrm{X}$ : Skor mentah sampel

$\mu \quad$ : Mean atau rata-rata

$\sigma \quad$ : Standar Deviasi

Berdasarkan norma diatas, maka diperoleh kategorisasi subjek penelitian pada variabel regulasi diri dan prokrastinasi akademik sebagai berikut :

Tabel 3: Kategori Regulasi Diri dan Prokrastinasi Akademik

\begin{tabular}{|c|c|c|c|c|}
\hline Variabel & Skor & Jumlah & Persentase (\%) & Kategori \\
\hline \multirow{3}{*}{ Regulasi Diri } & $64-79$ & 18 & $45 \%$ & Rendah \\
\cline { 2 - 5 } & $80-89$ & 17 & $42 \%$ & Sedang \\
\cline { 2 - 5 } & $90-104$ & 5 & $13 \%$ & Tinggi \\
\hline \multirow{3}{*}{$\begin{array}{c}\text { Prokrastinasi } \\
\text { Akademik }\end{array}$} & $64-67$ & 2 & $5 \%$ & Rendah \\
\cline { 2 - 5 } & $67-84$ & 35 & $87 \%$ & Sedang \\
\cline { 2 - 5 } & $85-112$ & 3 & $8 \%$ & Tinggi \\
\hline
\end{tabular}

Berdasarkan tabel 6 di atas dapat diketahui pada variabel regulasi diri diperoleh gambaran regulasi diri bahwa mahasiswa pada kategori tinggi yaitu berjumlah 18 orang (45\%), kategori sedang berjumlah 17 orang (42\%) dan 5 orang (13\%) untuk kategori rendah, sedangkan untuk variabel prokrastinasi akademik mahasiswa pada kategori tinggi yaitu berjumlah 2 orang (5\%), kategori sedang berjumlah 35 orang 87\%) dan 3 orang (8\%) untuk 
kategori rendah. Hal ini dapat disimpulkan bahwa rata-rata subjek penelitian memiliki regulasi diri dan prokrastinasi akademik dalam kategori yang sedang.

\section{Sumbangan Efektif}

Besar sumbangan variabel regulasi diri terhada prokrastinasi pakademik, dapat ditentukan dengan menggunakan rumus korelasi parsial. Koefisien parsial adalah sumbangan efektif variabel independen yaitu regulasi diri terhadap variabel dependen yaitu prokrastinasi pakademik. Rumus yang digunakan untuk korelasi parsial adalah sebagai berikut :

$$
\begin{aligned}
& \mathbf{K P}=\mathbf{r}^{\mathbf{2}} \mathbf{. 1 0 0 \%} \\
& \text { Keterangan: } \\
& \begin{aligned}
\mathrm{KP} \quad & =\text { Korelasi parsial } \\
\mathrm{r} \quad & =\text { Nilai koefisien korelasi } \\
\mathrm{KP} & =\mathrm{r}^{2} \times 100 \% \\
& =-0,378^{2} \times 100 \% \\
& =0,142884 \times 100 \% \\
& =14,2884 \% \\
& =14 \%
\end{aligned}
\end{aligned}
$$

Berdasarkan rumus tersebut maka dapat ditentukan bahwa besarnya sumbangan regulasi diri terhadap prokrastinasi akademik adalah sebesar $14 \%$ dan $86 \%$ lagi dipengaruhi oleh faktorfaktor lainnya seperti seperti kecemasan, self depreciation, rendahnya toleransi terhadap ketidaknyamanan, pencari kesenangan, tidak teraturnya waktu, tidak teraturnya lingkungan, pendekatan yang lemah terhadap tugas, kurangnya pernyataan yang tegas, permusuhan dengan orang lain, dan stress dan kelelahan (Bernard dalam kurniawan, 2013). ${ }^{[1]}$

\section{KESIMPULAN}

Terdapat hubungan yang signifikan antara regulasi diri dengan prokrastinasi akademik pada mahasiswa KSR PMI di Universitas Negeri Padang dengan arah negative, hl ini berarti semakin tinggi regulasi diri, maka semakin rendah prokrastinasi akademik. Sebaliknya, semakin rendah regulasi diri, maka semakin tinggi prokrastinasi akademik, dengan demikian hipotesis diterima. Besarnya sumbangan efektif regulasi diri terhadap prokrastinasi akademik adalah sebesar $14 \%$, sedangkan $86 \%$ yang lain.

\section{DAFTAR PUSTAKA}

[1] Alfiana, A.D, 2013. Regulasi Diri Mahasiswa Ditinjau Dari Keikutsertaan Dalam Organisasi Kemahasiswaan. Jurnal Psikologi, 1 (2).

[2] Anggawijaya,S. 2013. Hubungan Antara Depresi Dan Prokrastinasi Akademik. Jurnal Ilmiah Mahasiswa Universitas Surabaya Vol 2 No. 2

[3] Ardi, M \&Aryani, 2010. Hubungan Antara Persepsi Terhadap Organisasi Dengan Minat Berorganisasi Pada Mahasiswa Fakultas Psikologi Uinsuska. Diakses Pada Tanggal 20 Agustus 2014. Http://Fpsi.Uin-Suska-Ac.Id/Sites/Default/Perpustakaan/Download/153Jurnal\%20ardi\%20linda\%20revisis-163.Pdf.

[4] Azhari, Teuku Riki Dan Mirza, Hubungan Regulasi Diri Dengan Kecemasan Menghadapi Dunia Kerja Pada Mahasiswa Tingkat Akhir. Universitas Syiah Kuala Mediapsi Vol. 2, No. 2,23-29. Unsyiah.

[5] Azwar, Saifuddin. 2014. Metode Penelitian. Yogyakarta:Pustaka Belajar.

[6] Azwar, Syaifuddin .2012. Penyusunan Skala Psikologi. Yogyakarta : Pustaka Belajar.

[7] Feist. 2010. Teori Kepribadian. Selemba. 
[8] Fitriya Dan Lukmawati. 2016. Hubungan Antara Regulasi Diri Dengan Perilaku Prokrastinasi Akademik Pada Mahasiswa Sekolah Tinggi Ilmu Kesehatan (Stikes). Mitra Adiguna Pelembang. Psikismjurnal Psikologi Kesehatan. Vol.2 No. I. Uin Raden Fatah.

[9] Ghufron, M. Nur dan Risnawati, Rini. 2010. Teori-Teori Psikologi. Jogjakarta: Ar-Ruzz Media.

[10] Hendrianur. 2015. Hubungan Dukungan Sosial Dan Regulasi Diri Dengan Prokrastinasi Dalam Menyelesaikan Skripsi. Jurnal Psikologi, 3(2), 528- 542. Retrieved From Http://Ejournal.Psikologi.Fisipunmul.Ac.Id

[11] Kurniawan, Rizki. 2013. Hubungan Antara Self Regulated Learning Dengan Prokrastinasi Akademik Pada Mahasiswa Jurusan Psikologi Universitas Negeri Semrang. Skripsi Fakultas Psikologi Universitas Negeri Semarang

[12] Liu, Heldihan Ting Dan Lee, Young Sun. 2015. Measuring Self-Regulation Second Language Learning: A Rasch Analiysis.

[13] Maharani, Dienda Tika 2016. Hubungan Antara Culture Shock Dengan Prokrastinasi Akademik Pada Mahasiswa Psikologi Universitas Putra "Yptk" Padang. Skripsi . Padang: Fakultas Psikologi Universitas Putra Indonesia (Yptk).

[14] Manab, A. 2016. Memahami Regulasi Diri: Sebuah Tinjauan Konseptual. Jurnal Psychology And Humanity, 7-11. Retrieved From Http://Mpsi.Umm. Ac.Id.

[15] Mulhamah, Dkk. 2016. Kemampuan Regulasi Diri Siswa Dan Dampaknya Terhadap Prestasi Belajar Matematika. Jurnal Review Pembelajaran Matematika, 1(1), 31-42. Doi: 10.15642/Jrpm.2016.1.1.31-42.

[16] Ormrod,J.E. 2008. Psikologi Pendidikan Membantu Siswa Tumbuh Dan Berkembang Jilid 2. Jakarta: Erlangga.

[17] Priyatno, D. 2008. Mandiri Belajar Spss. Yogyakarta:Mediakom.

[18] Purnamasari, Dkk. 2014. Hubungan Antara Regulasi Diri Dengan Prokrastinasi Menyelesaikan Tugas, Pada Assisten Mata Kuliah Praktikum, Jurnal, Surakarta.

[19] Rizanti, D. Fitriya. 2013. Hubungan Antara Self Regulated Learning Dengan Prokrastinasi Akademik Dalam Menghafal Al-Qur'an Pada Mahasiswa Ma'had'aly Masjid Nasional Al-Akbar Surabyas, Skripsi, Unesa, Surabaya.

[20] Santika, Dkk. 2016. Self-Regulated Learning Dan Prokrastinasi Akademik Pada Siswa Kelas Xi Sma Negeri 2 Purwokerto. Jurnal Psikologi Empati, 5(1), 44-49.

[21] Setyono, A. 2013. Pengaruh Keaktifan Berorganisasi Dan Kerajinan Beribadah Terhadap Kematangan Kepribadian Pada Mahasiswa Pai Semester Vi Sekolah Tinggi Agama Islam Negeri (Stain) Salatiga. Skripsi. Retrieved Juni..

[22] Sperling, S. Dkk. 2012. Academic Procrastination And Their Self-Regulation. Psychology, 3(1), 12-23. Doi: 10.4236/Psych.2012.31003.

[23] Sugiyono. 2014. Metode Penelitian Kuantitatif Kualitatif Dan R\&D. Bandung: Alfabeta.

[24] Suryabrata, Sumadi. 2011. Metodologi Penelitian. Jakarta. Rajawali Pers.

[25] Triyono. 2014. Hubungan Antara Efikasi Diri Dan Regulasi Emosi Dengan Prokrastinasi Akademiksiswa Sma. Tesis. Surakarta: Program Studi Magister Sains.

[26] Ursia, Nela Regeir. Ide Bagus Siaputra., Dan Nadia Susanto. 2013. " Prokrastinasi Akademik Dan Self-Control Pada Mahasiswa Skripsi Fakultas Psikologi Universitas Surabaya”. Makalah Seri Humaniore, Doi 10. 7454/Mssh. Vi 7 ii. 1798. 